\title{
Innovations in Healthcare Sector Connected to Industry 4.0
}

\author{
Zuzana Papulova, Silvester Krcmery \\ Department of Strategy and Entrepreneurship, Faculty of Management Comenius University in \\ Bratislava, Slovakia \\ zuzana.papulova@fm.uniba.sk
}

\begin{abstract}
With the development of the 4th Industrial Revolution, we can expect changes that could transform the very essence of humanity and every aspect of life in our planet. The 4th Industrial Revolution has already undoubtedly impacted a lot of sectors and industries along with healthcare. The purpose of the paper is to introduce the Healthcare 4.0 and evaluate trends and challenges coming with innovations of Industry 4.0 in the selected sector of healthcare. Numerous studies have come to conclusions that trends like digitalization, telemedicine or artificial intelligence could improve healthcare quality for patients and increase the efficiency and effectiveness of healthcare management. The Industry 4.0 will substantially change the healthcare in a relatively short time. The value of this paper is the investigation of the applicability, the challenges and the opportunities of the 4 th industrial revolution paradigms in the healthcare sector. Moreover, it provides an insight into the current state of healthcare in the context of Industry 4.0. The intention is to present possibilities coming with Industry 4.0 to improve healthcare services and to ensure and increase the safety of patients, the quality of life and other healthcare activities. As we can already learn from previous industrial revolutions, it is reasonable to expect that the Fourth Industrial Revolution will bring many opportunities, benefits, and promise to transform health and healthcare in medicine to become even more interconnected, more precise, and more democratic, with significantly improved human outcomes.
\end{abstract}

Keywords: Healthcare, Industry 4.0, Innovations.

\section{Introduction}

At present, there are often divergent views and discussions about the 4th Industrial Revolution. In many sectors, companies are actively preparing for changes related to this revolution, the dynamics of the environment, and this is not different in healthcare, where we can also speak about the so-called Healthcare 4.0 , Health 4.0 or eHealth. This technological revolution will bring a number of trends that will fundamentally change the way organization in healthcare works, such as the application of communication tools for patients and medical teams to intensify the transfer of treatment from hospital to home without interrupting outpatient services. 


\section{Theoretical background}

\subsection{Industry 4.0 and Healthcare 4.0}

The term "industry 4.0" is used to represent the 4th Industrial Revolution. We use the term "revolution" to indicate a sudden and radical change. Revolutions have occurred in history, when new technologies and unusual ways of perceiving the world have caused serious changes in economic systems and social structures. [1] Historically, scientific and technological development can be divided into several revolutions. The number 4.0 in the name means that we are now in the fourth phase of the industrial revolution. The first three revolutions were the result of a revolution in technology, electronics and mechanics, while the current phase of the industrial development of the 4 th industrial revolution - Industry 4.0 can be described as the revolution in informatics and communication. [2]

Each individual industrial revolution brought some level of scientific and technological development: [3-5]:

1. The first industrial revolution began in the late 18th century in England. Specifically, the year 1784 is taken as a significant milestone, when Edmund Cartwright invented the first mechanical loom. This revolution continued in the 19th century, when the transition from manual production in manufactories to large-scale machine production was being completed. At that time, new sources of energy began to be used especially the traditional symbol of this industrial revolution which is the steam power.

2. The second industrial revolution is associated with electrical power, mass production and assembly lines. It is usually associated with two dates, 1879, when Thomas Alva Edison invented the light bulb, and then 1870, when meat packaging companies in Chicago and Cincinnati installed the first assembly lines, which were later introduced by Henry Ford in the automotive industry.

3. The third industrial revolution is most often mentioned in the context of automation, electronics and the diffusion of information technology (IT). The key date is most often the year 1969, when the first programmable logic controller PLC was manufactured. This revolution is characterized by technological innovations in electronics and IT for automation and production. During this revolution, communication accelerated, and business contacts moved to a new level. This has created thousands of businesses and produced millions of jobs, laying the foundation for globalization in the $21 \mathrm{st}$ century.

4. The fourth industrial revolution is the revolution we are facing right now. It is characterized by the expansion of the internet, digitization and their penetration into virtually all the areas of human activity. In addition to people, machines and things are also connected to the network. Real and virtual worlds are beginning to overlap and cyber-physical systems (CPS) are coming into play.

As each revolution represents specific benefits in opportunities and quality of life improvements, we can also highlight specific development in healthcare sector moving from Healthcare 1.0 towards Healthcare 4.0 (Figure 1). Depending on various literature and complexity how to look at this development in healthcare, we can meet also with terms eHealth, Health 4.0 or Healthcare 4.0. 


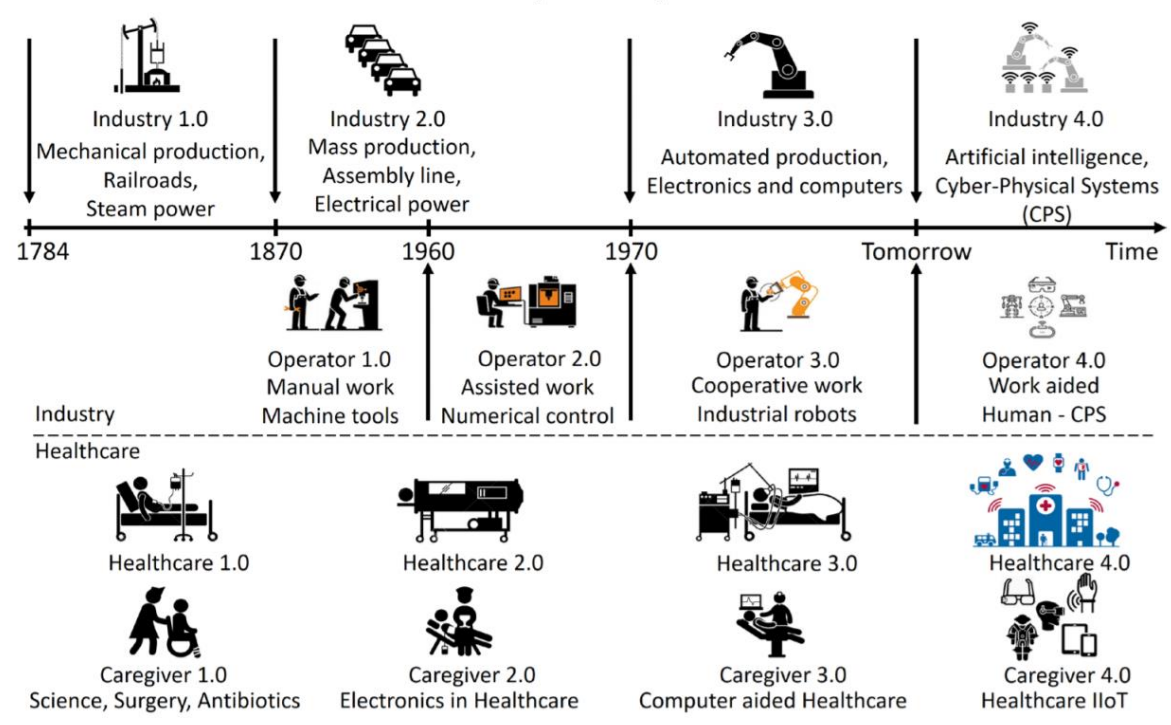

Fig. 1. Industrial revolutions [6]

As Industry 4.0 is completely changing both services and production sectors, it also encompasses healthcare. Technologies and concepts coming with Industry 4.0 as the Internet of Things, Cloud Computing, and Big Data technologies are revolutionizing eHealth and its whole ecosystem, moving it towards Healthcare 4.0 [7]:

1. Internet of Things (IoT) represents things and objects such as RFID, sensors, controllers, mobile phones that work together. IoT can serve as a huge network of interconnected "things" (including people) in relationships: human-human, human-machine, or machine-machine. A general vision of the IoT is a moving connectivity for anyone at any time and any place, forward to connectivity for anything, initially with focus on digital identification and machine to machine (M2M) communication. [8] We can also meet within Healthcare 4.0 with a more specific term "Internet of Medical Things" (IoMT) as a healthcare application of IoT technologies which envisions a network of connected devices that sense vital data in real time. IoMT has been enabled by the development of wireless sensor-based systems, nanotechnology and miniaturization. It is now possible to interconnect personal digital devices, medical devices, implants and other sensors wherein the sensors collect data, the micro-controllers process, analyze and wirelessly communicate data, and the microprocessors enable rich graphical user interface. [9]

2. Cloud Computing (Cloud) enables "Utility Computing", i.e. the leasing of computing resources (computational power, storage, and the related networking resources) in real time, with minimal interaction with the provider. [7] Cloud computing as a digital technology involves the delivery of computer system resources over the internet such as servers, storage, databases, networking, intelligence etc. This technology provides faster innovation and resources that are 
flexible, results in reduced operating cost and increased efficiency of running the infrastructure. [10]

3. Big Data technologies, where the term "big data" refers to very large volumes of data that are too complex for traditional data-processing tools. Big Data techniques are fulfilling the promise of extracting value (actionable information) from amounts of data previously unthinkable or unmanageable. [7]

\subsection{Innovations in Healthcare connected to Industry 4.0}

According Batra et al. [11], the healthcare industry development will be influenced by digital transformation and will focus more on sustaining well-being rather than responding to illness. New technologies will serve primarily for prevention and early diagnoses, also reaching the centre of the healthcare industry for a closer collaboration among industry stakeholders, and new combinations of services.

Areas of innovations associated with industry 4.0 in the field of healthcare are: [9, $11,12]$

1. Self-diagnostic systems for patients. Innovation in this area is leading to patients having access to detailed information about their own health and letting them make decisions about their health and well-being. Self-diagnostic systems e.g. in the form of wearable devices will allow patients to monitor their health. In this way, diseases and deteriorating health can be diagnosed in time and without patients having to go to a clinic or hospital. We are already using wearable devices to track our steps, sleep patterns or heart rate. People are growing accustomed to wearable devices that track activity. E.g. Deloitte's 2018 US Health Care Consumer Survey showed that consumers are tracking their health and fitness data two and a half times more today than they were in 2013 [11]. According to a report from World Economic Forum, [9], over 318,000 health applications are now available (double from just two years ago) on top applications stores worldwide with more than 200 health applications being added each day. This trend is most likely going to grow. Patients will likely demand that their health information be portable or maybe even invisible. Trends are also pointing out to other tech-enabled appliances equipped with remote-monitoring biosensors to detect and analyze health information. Monitoring of health conditions will help identify risks and illness which can be addressed early. These systems will contribute to support solutions for self-management.

2. Patient monitoring. In today's hospitals, the ability to have available and updated values of the necessary patient parameters is a key element. An important requirement is that the system be as economical as it is accessible from the point of view of the possibilities of industry 4.0, also guaranteeing remote access of doctors. Prospects for the future are to build automated hospitals, in which the patient's health status in the system is completely displayed as soon as he is admitted to the hospital. 
3. Digital data archive. In the healthcare, an increasing volume of data from within and outside traditional healthcare settings has the potential to contribute in improving decision-making and address inefficiencies. The aim of digital data archives is to integrate devices with digital medical records to ensure that the information on the patient's condition, the state of care and the state of the therapies to which he or she has been and will continue will constantly and automatically be updated.

4. Use of artificial intelligence (AI). AI is beginning to play an increasingly important and decisive role in diagnosis and therapy most especially as it helps in supporting diagnostics. There are seven main areas of AI in medicine: skin cancer diagnostics, eye disease diagnostics, new drug development, coma awakening prediction, X-ray and CT reading, depression diagnostics and robotic doctors with encyclopedic knowledge. [13] Misdiagnosis is a concerning issue in medicine, with studies revealing that at least one adult patient in 20 is misdiagnosed every year in the US, with half of these errors being potentially harmful [14]. AI also helps in improving processes related to organizing and managing medical records and data, identifying and addressing business workflows inefficiencies and cutting billing errors. In healthcare, AI can provide tremendous help in analyzing complex medical data such as radiographs, CT scans, and various screenings and tests. Using patient data and external sources of knowledge such as clinical research, healthcare professionals can be prepared a proper treatment for everyone. There are already specific applications such as: Babylon AI to consult with patients, virtual nurses Molly, or Microsoft's project Hanover to forecast the most effective cancer treatment for the patients. [15].

5. Coordination and cooperation. The same patient can often be examined and admitted by different professionals, and therefore coordination and cooperation should be ensured to allow the exchange of useful information. For this reason, information sharing is essential. Scientific and technological advances in medicine promise to transform health and healthcare so that they become even more interconnected, more precise and more democratic, with significantly improved human outcomes.

As Batra et al. [11] suggest, similar as in other industries, fundamental shifts in innovation tend to occur in seven-year cycles (figure 2) and healthcare is no different. They expect the change in healthcare industry to be influenced by trends underlying exponential growth like nanotechnology, quantum computing, robotics, biomedical engineering, artificial intelligence, connectivity, augmented reality and 3D printing. 


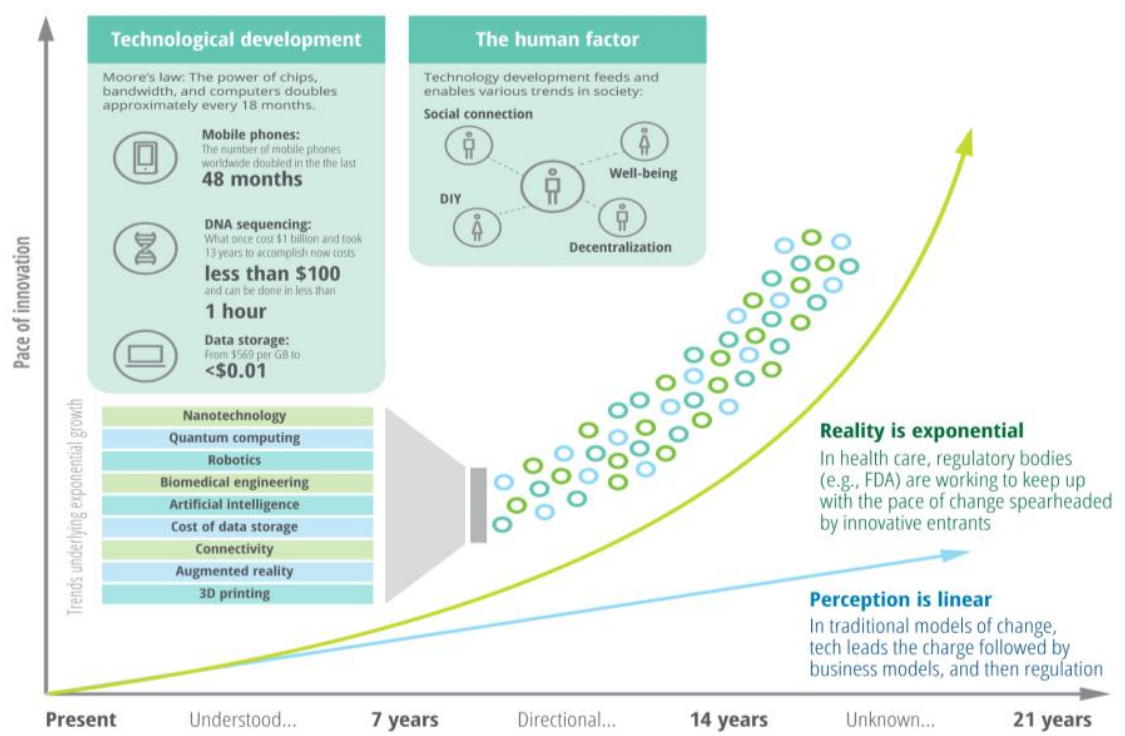

Fig. 2. Pace of innovation in healthcare [9]

According report from World Economic Forum, innovations and technologies in healthcare can also bring risks and raise important questions. Rising healthcare spending and the unaffordability of treatments are already a global challenge, and there are concerns that expensive new treatments and technologies will only exacerbate these trends. Technology may deepen healthcare inequalities by perpetuating existing biases in research results based on data that might lack diversity of gender, race and age. [9] Health professions certainly will need to acquire new knowledge, also connected to participation on bringing innovation [16] and top management will need to acquire skills suitable for challenges provided by management 4.0 specifics. [17]

\section{Goal and Methodology}

The aim of the paper is to provide a basic overview of the innovations in healthcare connected to the 4th Industrial Revolution. Within the structure of the paper, the first subchapter of the theoretical background deals with the developmental stages of the industrial revolution and the characteristics of industry 4.0. The second subchapter presents the results of our research in the healthcare industry correlating with its development and the challenges associated with industry 4.0. In chapter Results and Discussion, we present the examination the innovations in healthcare industry in Slovakia connected to Healthcare 4.0 and the state of eHealth also with some comparisons.

The research methodology is based on the analysis of theoretical knowledge and starting points in the field of the industrial revolution, developments in healthcare and individual trends bringing industry 4.0 and Healthcare 4.0. For the elaboration of this article, several research methods were used, which in a complex point of view form a 
logical ordered pattern. The given research methods were mutually combined and connected for the purpose of fulfilling the aim of our research. The combination of methods followed a logical thematic continuity. The information and data that were used in our article were processed by specific methods, thanks to which the effect of accurate, high quality and relevant information was achieved. We analyzed data from OECD countries from years 2013 to 2019 and compared them with data from the Slovak Republic. Data from the Ministry of Health of the Slovak Republic, the National Health Information Center (NHIC), eHealth portal of Slovak republic and the Statistical Office of the Slovak Republic were also used for conducting our research. The last update of the data, which we included in our research, was in the December 2020. Literature search is based on a large number of sources and databases (Web of Science, SCOPUS, Google Scholar, Library). The search strategy included Slovak and English, in which the main keywords were searched: Industry 4.0, Health 4.0, eHealth, healthcare, digitization, automation, innovations, the industrial revolution, technological trends, challenges in healthcare, etc. We also conducted interviews, data collection and processing and followed by interpretation of findings and formulation of conclusions. The results of our work, which we obtained using the application of various mathematical and statistical methods, were then clearly processed into graphs and tables with subsequent interpretation.

\section{$3 \quad$ Results}

\subsection{Development of Slovak eHealth and innovation solution in healthcare}

Scientific and technological advances in medicine promise to transform health and healthcare so that they become even more interconnected, more precise and more democratic, with significantly improved human outcomes. The use of information and communication technologies (ICT) in healthcare has clearly demonstrable benefits. The focus on electronic healthcare (eHealth) was supported by the European Parliament, when in 2009 created a proposal for a directive on the application of patients' rights in crossborder healthcare, which includes measures to improve cooperation between Member States in the field of electronic healthcare [19].

In 2013, the strategic framework of the Ministry of Health of the Slovak Republic in the field of healthcare was created. In this document was admitted that the key decision of area of Slovak healthcare were before often prepared without sufficient understanding and identification of the real problems. The ambition was to identify current problems of Slovak healthcare sector, to find measurable indicators and set objectives achievable by 2030. This was prepared in connection for assumed functional reception and transfer of information between hospitals and other healthcare facilities of inpatient and outpatient healthcare using Healthcare 4.0 solutions, emphasized on the continuity of healthcare during patient transition within individual environments. [14]

In the course of 2017, a communication plan was developed, which contained goals and activities aimed at individual target groups - the professional public (e.g. healthcare professionals, healthcare providers), the media, and the general public (patients). In the 
initial phase of communication, special attention was paid specially to increasing awareness and education of the professional public. Representatives of the NHIC participated in dozens of professional conferences and seminars in order to provide as much information as possible, to explain the function of the Slovak eHealth system and its benefits for all stakeholders. [19]

Program of eHealth implementation in the Slovak healthcare system is being implemented through several projects. Currently implemented project is National project Electronic Health Services (ESZ, also known as eSO1) financed from EU structural funds in the form of the Operational Program Informatization of Society. The mission of health care is to make a significant contribution to improving the quality of life of citizens by reducing mortality, morbidity, permanent and temporary consequences of diseases and injuries; providing health care, operating public health, supporting individual and community health care. The mission of eHealth is to support the mission of healthcare through information and communication technologies. The vision of eHealth is to provide the right information at the right time in the right place at all stages and processes of citizens' healthcare. [20]

The system of eHealth in Slovakia (eZdravie) has been active as a web portal (https://www.ezdravotnictvo.sk/) since 1 January 2018 with the following functions [21]:

- $\quad$ patient access via an insured person's card or via an electronic citizen's card with an electronic chip (eID) and doctor's access via an electronic health care card (ePZP) - access to the health system function

- creation of an electronic record from the examination and the exchange ticket - e-examination function,

- electronic prescription and dispensing of medicine, medical devices and dietetic food - e-prescription (e-recept),

- access to the patient's medical records via the electronic health book on the National Health Portal - electronic health book function

- $\quad$ ordering a doctor via the Internet during additional office hours for a specific date and time, or creating a request for an appointment during office hours e-order function,

- document with a basic overview of the patient's clinical data - patient summary function. 


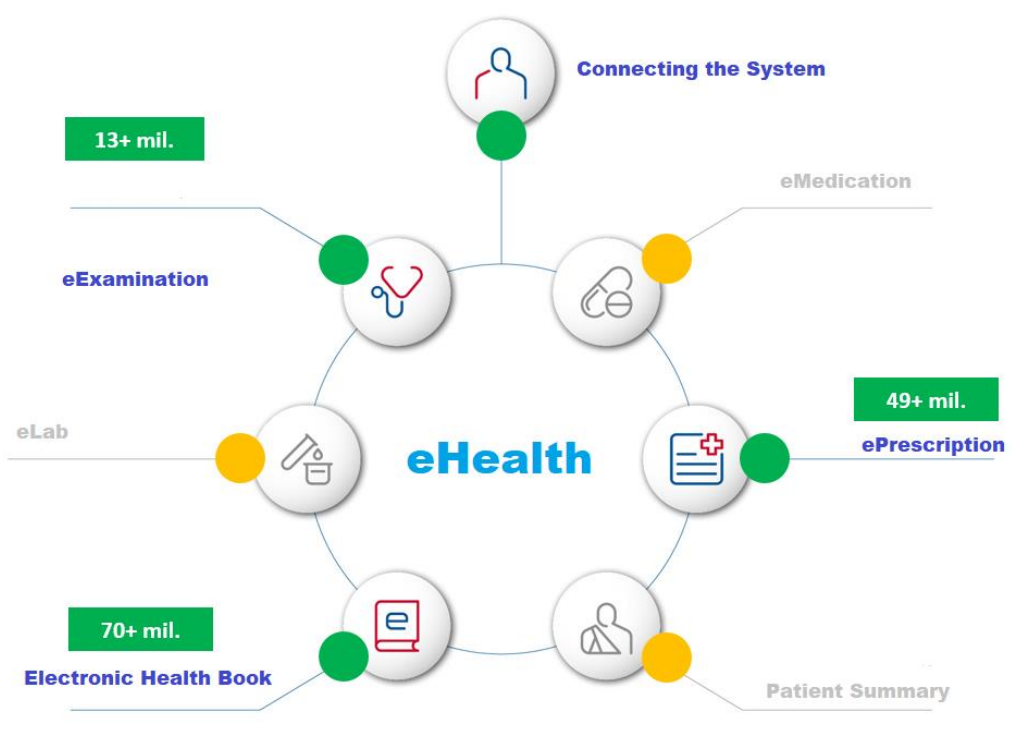

Fig. 3. Current status of eHealth [21, 22]

The Slovak eHealth is going to be composed by these components: [22]

- Connecting the System - health records of patients are stored in the National Health Information System (eHealth System). Therefore, a secured approval of the patient, as well as of the health professional who creates or accesses the health records is important;

- eExamination is basically creating an electronic record from the examination which almost replaces the paper health record. The physician after/during the examination creates an electronic record, which is a part of the eHealth System. More than 13 million records of professional examinations;

- eLab - creation of a record on results from a laboratory examination, yet to be deployed;

- Electronic Health Book is a health documentation of a patient in electronic form. On behalf of security and record protection, the patient accesses his health book via his eID or electronic proof of residence via National Health Portal. More than 70 million electronic patient records;

- Patient Summary is a cluster of the most important patient information. Thanks to which, the health professional has a rapid access to data on the health status of the patient;

- ePrescription is an electronic prescribing and dispending of medicines, medical devices or dietetic food contributes for effective and meaningful treatment of a patient, and to promote its safety. It enables interaction check yet at prescribing, and at the same time avoids duplicities. Since 2018, there were more than 134 million of e-recipes prescribed with 4,6 million EUR savings on costs.

- $\quad$ Medication - yet to be deployed. 
Despite initial difficulties, eHealth in Slovakia is gradually growing. According to the President of the Slovak Chamber of Pharmacy, Ondrej Sukel', experience with health is more positive than negative. Despite of some technical problems, mainly related to the start-up of the eHealth system, it brings tangible benefits for patients. Some doctors maybe still do not trust the eHealth but we can see a positive increase in statistic of usage. Also, there are some recommendation to patients to protect their personal data more rigorously in choosing their prescription drugs. Until 2021, a transitional period applies, when the pharmacist has access to prescription records also on the basis of the reported birth number of the patient. [23]

One of the latest actions, in the pandemic situation of SARS-CoV-2, the application My eHealth (Moje ezdravie) has started and is currently available in the App Store for iOS. It informs Slovaks about current measures and regulations related to the new coronavirus. It was prepared by the National Center for Health Information (NCZI) to raise awareness of SARS-CoV-2. [24]

\subsection{Evaluation of experiences with Healthcare 4.0}

What can we take from countries which are ahead of us? There are some examples of goal setting in the world. For example, in New Zealand, 5 indicators are evaluated quarterly at the regional level: length of emergency stay, speed of cancer treatment, immunization, help for smokers, healthy children (BMI index assessment). An indicator of access to elective surgery is being prepared, but on the contrary, they have omitted an indicator of the number of cardio and diabetic examinations. Each goal has its "champion", i.e. a specific person responsible for achieving that specific goal. In terms of Healthcare 4.0 solution, in 2013, the Slovak Republic made a Strategic framework for health for years 2014 - 2030, setting goals for those upcoming years in this particular heath sector area of concern. In table 1 is the progress made so far. [19, 25]

Table 1. eHealth tools for transformation. [19, 22, 26]

\begin{tabular}{lcccccc}
\hline & Unit & $\begin{array}{c}\text { Slovakia } \\
\text { year } \\
\mathbf{2 0 1 3}\end{array}$ & $\begin{array}{c}\text { Slovakia } \\
\text { year } \\
\text { Variable }\end{array}$ & $\begin{array}{c}\text { OECD } \\
\text { average } \\
\text { (2013) }\end{array}$ & $\begin{array}{c}\text { Top 5 } \\
\text { OECD } \\
\text { (2013) }\end{array}$ & $\begin{array}{c}\text { Target index, } \\
\text { Slovakia year } \\
\text { 2030 }\end{array}$ \\
\hline $\begin{array}{l}\text { Providers of } \\
\text { health services } \\
\text { involved in system }\end{array}$ & $\%$ & 0 & 99 & 20 & 95 & 99 \\
$\begin{array}{l}\text { Population with } \\
\text { eHealth accounts }\end{array}$ & $\%$ & 0 & 99 & 25 & 95 & 99 \\
$\begin{array}{l}\text { Number of entries } \\
\text { into Electronic }\end{array}$ & $\begin{array}{l}\text { Millions } \\
\text { per year }\end{array}$ & 0 & 70 & - & - & 350 \\
$\begin{array}{l}\text { Health Book } \\
\text { Number of items on }\end{array}$ & $\begin{array}{l}\text { Millions } \\
\text { per year }\end{array}$ & 0 & 49 & - & - & 215 \\
\hline
\end{tabular}


Target index is already met in terms of providers of health services involved in the system and population with the eHealth accounts. Basically, everyone who has medical insurance is in the system. However, number of entries into the Electronic Health Book and number of items on ePrescription is not up to par yet.

Currently, the total number of Healthcare workplaces connected to eHealth is 18,079 and there is currently 13,123 of Doctor's offices connected to eHealth according to NHIC. (see Fig. ). [22, 21]

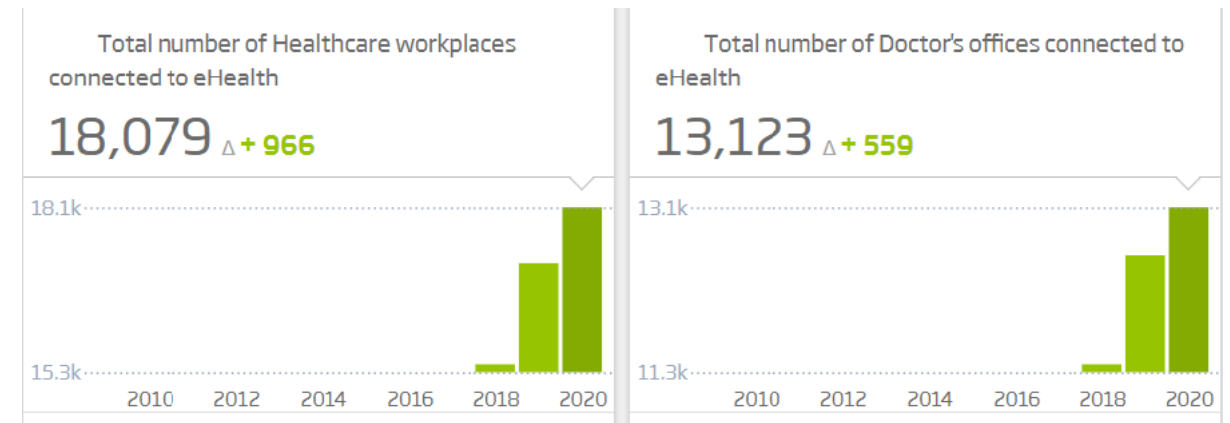

Fig. 4. Total number of Healthcare workplaces count from 1st of January 2018, where patient's health records are written into eHealth. [19, 21]

The annual growth of subjects connected in eHealth between the year 2018 and 2019 was 1694 units in terms of Healthcare workplaces and 1216 of Doctor's offices. Moreover, between the year 2019 and 2020, the change was more subtle but still apparent, 966 units in terms of Healthcare workplaces and 559 in the number of Doctor's offices respectively. On top of that 2099 (98\%) of all pharmacies and dispensaries of medical supplies are connected to eHealth as well as 123 hospitals. This implies roughly 18,412 of doctors connected to eHealth according to the statistics of NHIC. [21, 27]

Currently, there is almost 57 million of prescribed receipts in eHealth. Regarding the dispensed receipts in eHealth, the number is slowly climbing towards the 60 million mark. Furthermore, we can see a strong decline in the progress of dispensed receipts in eHealth during 2020, which may have a strong correlation the SARS-CoV-2 virus pandemic, while the numbers of prescribed receipts in eHealth had just a minor decrease. 


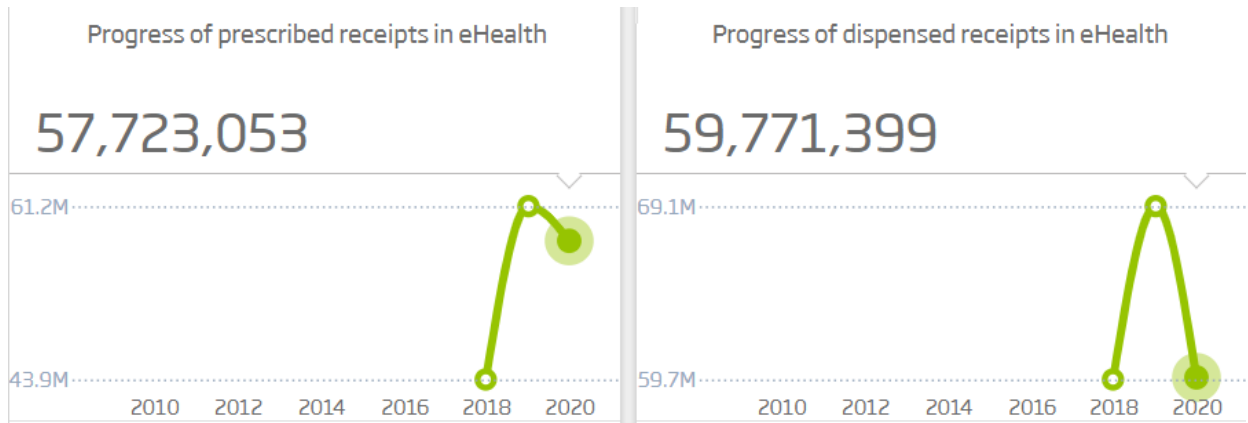

Fig. 5. Progress of prescribed receipts in eHealth alongside with the progress of dispensed receipts in eHealth from 1st of January 2018. [19, 21]

Healthcare systems and facilities have urgently had to adapt to the inevitable changes and will have to do so again in the future. Organizations will need to effectively manage change and become "masters of change" in this dynamic environment. We are already witnessing various extreme situations, such as the SARS-CoV-2 virus pandemic, which is directly affecting many aspects of the world and directly testing preparedness across many sectors, led by healthcare.

\section{Discussion}

Innovation is currently a key area for businesses, not only for industries but for all sectors and healthcare is no exception. The rapid pace of innovations in science and technology in the Fourth Industrial Revolution has important implications for healthcare. It brings key changes, concepts and trends related to digitization, automation, computerization and technology to the forefront. The connection of doctors, patients, data and machines will bring big changes in terms of medical treatment, but also in terms of the technology. From a review of the literature, it is clear that these changes will bring great challenges to hospitals and also provide enormous opportunities for their existence and future development. The individual authors cite many challenges and opportunities for the Fourth Industrial Revolution and healthcare, which will affect all subjects. Most authors agree that the way to deal with these changes is through working together and creating networks. Physicians and patients will be an integral part of the multi-stage innovation process, and universities can be an important source of know-how and a partner for innovation cooperation.

Industry 4.0 brings many positive elements, therefore is a major challenge for healthcare sector also. The specific challenges associated with industry 4.0 in the field of healthcare are: [12] the penetration of innovations into healthcare is prevented by administrative (bureaucracy, lengthy processes), cultural (resistance of participants in the system to change), but most especially financial obstacles. Finances in the Slovak healthcare system are planned on the basis of short-term (in practice only one-year, 
budget outlooks are only formal) budgets. In such environment, viewing through a "cash flow view" dominates.

However, it is also possible to look at innovations from an "investment perspective". In this sense, innovation is an investment with a high current cost, but able to bring benefits in the future. In some investment horizon, these benefits will subsequently outweigh the costs. For example, just in 2019, there was two big Healthcare 4.0 projects, one for more than 15 million EUR and the second one for more than 12 million EUR (with annual operating costs of 1,6 million EUR after the end of the project). On the other hand, the financial savings resulting from the introduction of the ePrescription from 1.1. 2018 is calculated to be roughly 15 million as well. The amount is the sum of the savings on the part of the patient and the doctor. [22, 28]

The inability to capitalize on investment in innovation is a more complex systemic problem. For example, more effective therapy will begin in the coming years to reduce patients' dependency, save social resources and keep patients in the work process for a longer time period which will inevitably save costs. However, these gains come back to healthcare with a delay, since they spread over time and manifest themselves in many places in the system. At the end, they only get back into healthcare by detour and all these positive elements are unfortunately less visible that way. The solution is to work with budgets with a multiannual horizon, quantify the possible benefits of innovation in the distant future and institutionalize and automate the process of capitalization of investment in innovation.

The main challenges are the systematic collection, verification and evaluation of data, which will not be self-serving and burdensome for medical staff and which will be an input to other activities. Furthermore, creating an environment with access to innovative medicines, techniques, technology and with the absorption of innovation in general.

\section{Conclusion}

The 4th Industrial Revolution is a contribution to building smart factories and smart hospitals, where software, technologies and processes can effectively deliver better results in less time and at a lower cost. In the near future, Industry 4.0 will eventually inevitably change healthcare.

We can argue that Healthcare 4.0 could borrow concepts according to Industry 4.0 standards. The value of this paper is to examine the applicability, challenges and opportunities of the paradigm of the 4th Industrial Revolution in healthcare. In addition, it provides an insight into the current state of healthcare in the context of Industry 4.0. This paper gives the reader an overview of Healthcare 4.0, the challenges in healthcare in the 4th Industrial Revolution and provides an overview of the current state, the possible benefits of individual innovations and cooperation with other actors in the innovation process.

The limit of our contribution is mainly the lack of scientific studies, as well as the fact that it is still only the initial stage of industry 4.0 and our research in healthcare, and thus a limited amount of empirical data. 


\section{Acknowledgements}

This research was supported and funded by APVV-17-0656 titled Transformation of Paradigm in Management of Organizations in the Context of Industry 4.0.

\section{References}

1. Schwab, K.: The Fourth Industrial Revolution. World Economic Forum, Geneva (2016).

2. Molnár, K.: Perspektívy možností aplikácie štandardov Industry 4.0, https://www.engineering.sk/clanky2/stroje-a-technologie/3322-perspektivy-moznosti-aplikacie- standardov-industry-4-0, last accessed 2020/06/21.

3. Cejnarová, A.: Od 1. průmyslové revoluce ke 4, https://www.technickytydenik. cz/rubriky/ekonomika-byznys/od-1-prumyslove-revoluce-ke-4_31001.html, last accessed 2020/06/21.

4. Ješko, V.: Štvrtá priemyselná revolúcia, http://www.fiercepharma. com/regulatory/gskjumps-on-smart-inhaler-bandwagon-elliptasensor-deal, last accessed 2020/06/21.

5. Kohnová, L., Salajová, N.: Industrial Revolutions and their impact on managerial practice: Learning from the past. Problems and Perspectives in Management, 17(2), 462-478 (2019).

6. Katedra kybernetiky a umelej inteligencie, FEI, TUKE. Framework caregiver 4.0 \& checkup - cognitive healhcare platform, https://data.ciirc.cvut.cz/public/events/2018-09SetkKyberKateder/vyzku mne/Papcun_TU_Kosice.pdf, last accessed 2020/06/20.

7. Aceto, G., Persico, V., Pescapé.: A. Industry 4.0 and Health: Internet of Things, Big Data, and Cloud Computing for Healthcare 4.0. Journal of Industrial Information Integration, 18, $1-13(2020)$.

8. Atzori, L. Iera, A. Morabito,G.: The internet of things: a survey, Computer Networks, 54 (15), 2787-2805 (2010).

9. World Economic Forum, Health and Healthcare in the Fourth Industrial Revolution Global Future Council on the Future of Health and Healthcare 2016-2018, http://www3.weforum.org/docs/WEF_Shaping_the_Future_of_Health_Council_Report. pdf, last accessed 2020/06/18

10. Javaid, M. et al.: Industry 4.0 technologies and their applications in fighting COVID-19 pandemic. Diabetes \& Metabolic Syndrome: Clinical Research \& Reviews 14, 1871-4021 (2020).

11. Batra, N., Betts, D., Davis, S.: Forces of change: The future of health, https://www2.deloitte.com/us/en/insights/industry/health-care/forces-of-change-healthcare.html, last accessed 2020/06/17.

12. Cassettari, L., et al.: Industry 4.0 and its applications in the Healthcare Sector: a systematic review. In: XXIV Summer School "Francesco Turco" - Industrial Systems Engineering, pp 136-142. (2019).

13. Štedroň et al.: Prognostika. 1st ed. C.H.Beck, Praha (2019).

14. Graber, L. The incidence of diagnostic error in medicine. British Medical Journal,;22 (2),21-27 (2014)

15. Štedroň et al.:Právo a umelá intelligence. $1^{\text {st }}$ ed. Vydavatelství a nakladatelství Aleš Čenek, Plzeň (2020).

16. Stacho, Z.; Stachova, K.; Caganova, D. Participation of all Employee Categories in Innovation Processes in Slovak Organisations. Mobile Networks and Applications, 1-7 (2020) 
17. Blštáková, J., Bednár, R., Adamková, H., Joniaková, Z., Ljudvigová, I., Némethová, I., Skorková, Z.: Human Resources Management 4.0 : Architecture, Roles, Leadership, and Business Models. 1st Edition. Verlag Dr. Kovač, Hamburg (2019).

18. Euroaktiv, Slovensko bližšie k aplikáciam e-health, https://euractiv.sk/section/informacnaspolocnost/news/slovensko-blizsie-k-aplikaciam-e-health/, last accessed 2020/04/21.

19. Ministry of Health: Strategic framework for health for 2014 - 2030, https://www.health.gov.sk/? strategia-v-zdravotnictve, last accessed 2020/04/21.

20. Slovensko.sk, e-zdravotnictvo, https://www.slovensko.sk/sk/agendy/agenda/_e-zdravotnictvo/, last accessed 2020/06/21.

21. eZdravie homepage, https://www.ezdravotnictvo.sk/sk/-/connectathon-20-11-2020, last accessed 2020/06/21.

22. NCZI, Výročná správa, http://www.nczisk.sk/en/Pages/default.aspx, last accessed 2020/06/21

23. Lekarnici.sk, Skúsenosti s ezdravím sú viac pozitívne ako negatívne, tvrdí prezident Slovenskej lekárnickej komory Ondrej Sukel', http://www.lekarnici.sk/?p=3293, last accessed 2018/07/25.

24. TASR, Aplikácia Moje ezdravie informuje Slovákov o novom koronavíruse, https://www.teraz.sk/slovensko/aplikacia-moje-ezdravie-informuje-slov/455396clanok.html, 2018/04/25.

25. Ministry of Health, Health targets, https://www.health.govt.nz/new-zealand-health-system/health-targets, last accessed 2020/06/21.

26. OECD, Dataset on Health Status in OECD.Stat, http://stats.oecd.org /Index.aspx ?DataSetCode=HEALTH_STAT last accessed 2020/06/21.

27. Štatistický úrad SR, Zdravie https://bit.ly/3dmIRKv last accessed 2020/06/21.

28. eZakazky - Elektronické verejné obstarávanie, https://www.ezakazky.sk/ index.cfm?Module=Item\&Page $=$ ItemDetailUvo\&TenderID=28684\&fbclid=IwAR30gdgyEiCQeyO18nhldGpSmClldZO8cWerVA8yCZUyV4dwauElrWzdTDI last accessed $2020 / 06 / 21$ 